\title{
Vulval myiasis: a rare entity
}

\author{
Anchit Wapa $^{1 *}$, Anu Namgyal ${ }^{2}$, Anu Devi \\ ${ }^{1}$ Department of Ophthalmology, ${ }^{2}$ Department of Obstetrics and Gynecology, Regional Hospital, Kullu, Himachal \\ Pradesh, India
}

Received: 24 September 2017

Revised: 29 January 2018

Accepted: 31 January 2018

\section{*Correspondence:}

Dr. Anchit Wapa,

E-mail: dr.anchitwapa@gmail.com

Copyright: (c) the author(s), publisher and licensee Medip Academy. This is an open-access article distributed under the terms of the Creative Commons Attribution Non-Commercial License, which permits unrestricted non-commercial use, distribution, and reproduction in any medium, provided the original work is properly cited.

\section{ABSTRACT}

Human myiasis refers to parasitic infestation of body tissues by larvae of several fly species. The entity has a simple management. It is well-documented in the literature however genital myiasis in females is scarcely reported in the literature. We hereby report this entity in a female who presented in postnatal period with ulceration and severe pain in her vulvar region.

Keywords: Maggots, Perineal hygiene, Vulval myiasis

\section{INTRODUCTION}

Myiasis is defined as a disease caused by the infestation of dipterous larvae in various body wounds and orifices and is very rarely located in genital area with only $0.7 \%$ cases of vulvar myiasis reported. ${ }^{1-3}$

The distribution of myiasis is worldwide, with more cases being reported from tropical, subtropical, and temperate areas. It occurs predominantly in rural areas in women with poor hygiene, mentally challenged, debilitated or immunocompromised patients. The diagnosis and management are simple in this rarely found entity.

\section{CASE REPORT}

Here we report a case of 19-year-old lady who presented to obstetrics and gynaecology department of a hospital in northern India, with severe vulvar pain associated with itching and ulceration for 5-6 days. She had a home delivery 14 days back. On examination she had stable vitals, without any associated factors and on local examination there was an ulcer measuring $4 * 3 \mathrm{cms}$ on the left vulva with a honeycomb appearance, necrotic appearance and slough with multiple tiny maggots of creamish white colour about 4 to $6 \mathrm{~mm}$ buried in the ulcerated area. On speculum examination cervix and vagina was healthy and pervaginally uterus was 12 weeks size and os was closed.

Laboratory investigations revealed haemoglobin of 10 $\mathrm{gm} / \mathrm{dl}$ with a normal lecocyte and platelet count, random blood sugar of $86 \mathrm{mg} \%$, normal urine routine and microscopy with negative serology for Human immunodeficiency virus, Hepatitis B and Syphilis and sterile culture. She was started on antibiotics and analgesics and under local anaesthesia the ulcer was cleaned with hydrogen peroxide and normal saline. About 16-17 maggots were picked up with forceps and wound was cleaned and Vaseline pack was kept.

On the next day again after thorough cleaning with hydrogen peroxide and normal saline 5 maggots were removed after which everyday dressings were done. On the following days no maggots were found, and the wound eventually healed with secondary intension. 


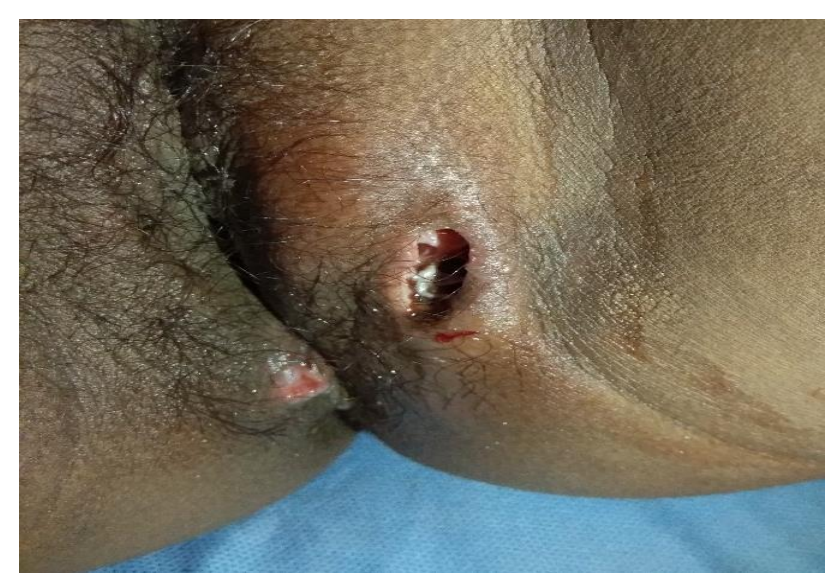

Figure 1: Ulceration on left vulva with multiple larvae.

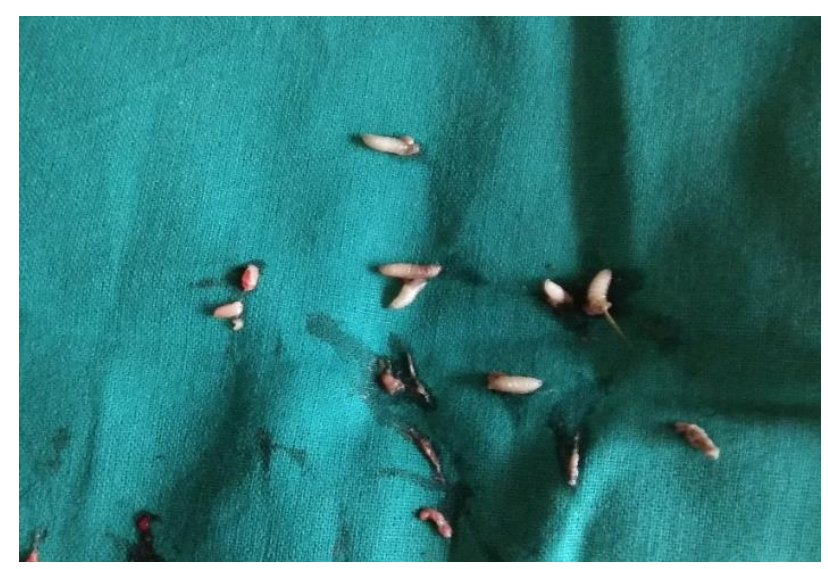

Figure 2: Larvae removed: multiple live.

\section{DISCUSSION}

Vulvar myiasis is a very rare entity which is completely preventable and easy to treat. Human myiasis can be classified as cutaneous myiasis, ocular myiasis, urogenital myiasis and intestinal myiasis based on clinical presentation. ${ }^{4}$ In the primary and furunculoid forms of the disease the larvae penetrate the skin, leading to the formation of painful, inflammatory nodules that can form fistula. ${ }^{3}$ The treatment consists of removal of the parasitic larvae and thorough cleansing of affected area with hydrogen peroxide, medical turpentine oil and Vaseline dressings to immobilise the larvae. The possible source in the present case may be the eggs, which were transmitted to the vulva via soiled clothes. The flies laid eggs on the clothes, as flies were attracted to the blood and body secretions hence resulting in vulvar myiasis. Though it is very rare to have this condition in a mentally and physically fit person, the lack of hygiene and poor knowledge of the patient maybe the cause of her reporting late to the hospital. Myiasis occurs predominantly in rural areas and is associated with poor hygiene practices and low education level. As poor hygiene is known to be associated with vulvar myiasis, washing and keeping the genital area clean may help in prevention of this condition. ${ }^{5,6}$

\section{CONCLUSION}

To conclude, vulvar myiasis in external genitalia is a rare entity, one of the causes of which maybe underreporting by the concerned health personnels. Role of health personnel is to educate patient about the role of good personal hygiene.

\section{Funding: No funding sources Conflict of interest: None declared Ethical approval: Not required}

\section{REFERENCES}

1. Kataria U, Siwach S, Gupta S. Myiasis in female external genitalia. Indian J Sex Transm Dis. 2013;34:129-31.

2. Raja AM, Vidhyashree, Pushpa Kotur P. Vulvalmyiasis in rural setting: a case report. Int J Adv Res. 2014;2:422-4.

3. Sherman RA. Wound myiasis in urban and suburban United States. Arch Intern Med. 2000;160:2004-14

4. Janovy J Jr, Schmidt GD, Larry S. Gerald D. Schmidt and Larry S. Roberts' Foundations of Parasitology. Dubuque, Iowa: Wm. C. Brown;1996.

5. Predy G, Angus M, Honish L, Burnett CE, Stagg A. Myiasis in an urban setting: a case report. Can J Infect Dis. 2004;15:51-2.

6. Yazar S, Ozcan H, Dinçer S, Sahin I. Vulvar myiasis. Yonsei Med J. 2002;43:553-5.

Cite this article as: Wapa A, Namgyal A, Devi A. Vulval myiasis: a rare entity. Int J Reprod Contracept Obstet Gynecol 2018;7:1231-2. 